\title{
Limpet grazing and loss of Ascophyllum nodosum canopies on decadal time scales
}

\author{
Andrew J. Davies ${ }^{1,2, *}$, Mark P. Johnson ${ }^{1}$, Christine A. Maggs ${ }^{1}$ \\ ${ }^{1}$ School of Biological Sciences, Queen's University, 97 Lisburn Road, Belfast BT9 7BL, UK \\ ${ }^{2}$ Present address: Scottish Association for Marine Science, Dunstaffnage Marine Laboratory, Oban, Argyll PA37 1QA, UK
}

\begin{abstract}
The role of limpet grazing in preventing the development of algal canopies is a recurrent theme in intertidal ecology. Less is known about interactions of limpets with the long-term dynamics of established canopies. Aerial photographs indicate that intertidal canopy cover has declined over the past $44 \mathrm{yr}$ in Strangford Lough, Northern Ireland. There has been a loss of the previously continuous cover of Ascophyllum nodosum (L.) Le Jolis in the mid-shore. A barnacledominated assemblage now fills gaps in the A. nodosum canopy. The rates at which barnacle patches become established and grow have increased since 1990. Changes in canopy cover have been accompanied by increases in limpet densities since the 1980s. Measurements between 2003 and 2004 showed no increase in length of $A$. nodosum fronds when limpets Patella vulgata had access to the algal holdfasts. In contrast, when limpets were experimentally excluded from the holdfasts, there was net frond growth. In the Isle of Man, which is climatically similar to Strangford Lough but has fewer limpets, growth occurred regardless of limpet grazing. The breaking force for $A$. nodosum declined with increasing local densities of limpets. A. nodosum is a sheltered shore species, potentially vulnerable to changes in wave exposure. There is no evidence, however, that Strangford Lough has become windier over the past 3 decades. Variation in wave exposure among locations within the lough was not related to rates of barnacle patch creation or expansion. Limpet population density has increased following a series of mild winters. Climate change may have a role in causing canopy loss, not by direct effects on the growth of fucoids, but by increasing the severity of grazing through changes to limpet populations.
\end{abstract}

KEY WORDS: Limpets · Ascophyllum nodosum · Patella vulgata · Grazing $\cdot$ Climate $\cdot$ Canopy loss Fucoid

\section{INTRODUCTION}

A canopy of fucoid algae is frequently seen as the defining characteristic of sheltered rocky shores (Lewis 1964). Fucoids often act as foundation species, creating habitat and modulating the flow of resources to other organisms (Dudgeon \& Petraitis 2005). A particularly striking example of such a foundation species is Ascophyllum nodosum (L.) Le Jolis, a mid-shore dominant along sheltered coasts of the North Atlantic. A. nodosum canopies may have a high biomass (Cousens 1984), and can influence biodiversity by facilitating other species (Jenkins et al. 1999). A. nodo- sum is relatively long-lived, with estimated holdfast ages exceeding 50 yr (Åberg 1992a,b). Given this longevity, it is perhaps unsurprising that the temporal dynamics of $A$. nodosum stands are not well understood. The majority of temporal work consists of studying the responses to catastrophic disturbances, whereby patches of mature plants are removed completely from the shore (e.g. by scraping and/or burning: Keser \& Larson 1984, Jenkins et al. 1999, Dudgeon \& Petraitis 2001, Bertness et al. 2004). While these experiments can define the recovery time of canopies, they do not necessarily reflect the dynamics of A. nodosum in areas where large-scale removal is rare 
or absent, such as the ice-free shores of the NE Atlantic.

In general, long-term time series studies of intertidal communities are a rarity, leaving ecologists to infer community dynamics on the basis of relatively shortterm experiments (Underwood 2000, but see Dye 1998). Where longer-term observations have been made, it is still difficult to assess drivers of ecosystem change. For example, in a 17 yr study of a shore in the Severn Estuary, England, Little \& Kitching (1996) identified wave action and limpet grazing as possible factors involved in the loss of a fucoid canopy. It has long been known that experimental removal of limpets leads to proliferation of fucoids (e.g. Jones 1946, 1948). Such experiments have contributed to a consensus that patellid limpets are the dominant grazers on NE Atlantic shores (e.g. Hawkins \& Hartnoll 1983). Removing limpets commonly results in a bloom of ephemeral green algae, followed by a dense coverage of fucoid species. Hence much research has emphasized the role of grazing in preventing establishment of canopy-forming Fucus spp. (e.g. Southward 1964, Southward \& Southward 1978, Hawkins 1981, Hawkins \& Hartnoll 1983, Jenkins et al. 1999, Thompson et al. 2004, Jonsson et al. 2006). In contrast to cases involving the grazing of juvenile algae or recruits, the loss of established canopies has been less studied, and it is not clear what role grazing may play. Furthermore, relatively few studies have recorded patellid grazing in Ascophyllum nodosum-dominated areas (but see Jenkins et al. 1999). Loss of adult plants is usually attributed to changes in physical disturbance (Little \& Kitching 1996) and has been observed as part of the recovery of limpet densities following oil spills and related impacts (Southward \& Southward 1978). Limpet grazing on established A. nodosum canopies has been observed sporadically on NE Atlantic shores (Fischer-Piette 1948, Southward 1964). It is therefore possible that limpets may play a role in the long-term dynamics of $A$. nodosum canopies by damaging or removing established adult algae.

For shores around the coast of Northern Ireland, preliminary observations suggested a trend of decreases in Ascophyllum nodosum canopy cover over the last decade. We were able to use aerial photographs of the intertidal zone in Strangford Lough (Northern Ireland) taken at various times between 1962 and 2002 to assess this suggested change in canopy cover. The possibility that grazing is associated with this loss could be assessed using survey data on limpet Patella vulgata L. densities between 1979 and 2004. Given these historical data, 2 potential hypotheses were tested as explanations for the observations of $A$. nodosum canopy loss (1) a change in environmental conditions (increased wave exposure, Little \& Kitching 1996) has resulted in the loss of adult plants; (2) a change in strength of the grazing effect of limpets on adult $A$. nodosum has increased the loss rate of adult plants. The 2 hypotheses are not mutually exclusive and $A$. nodosum loss may result from an interaction between environmental and trophic processes. To further quantify the potential role of limpets we manipulated grazing in 2 regions with similar climatic conditions but different densities of limpets. The relationship between limpet density and the breaking force for adult fronds was also estimated.

\section{MATERIALS AND METHODS}

Aerial photography. Aerial photographic surveys of Strangford Lough (Fig. 1) were made in 1969, 1994, 1997, 2001 and 2002 by the Environment and Heritage Service, Northern Ireland, and in 1962 and 1988 by the Ordnance Survey, Northern Ireland. Eleven locations photographed at more than one time were identified from these surveys (Table 1). Analysis was restricted to areas of bedrock as changes in cover on boulder shores were difficult to

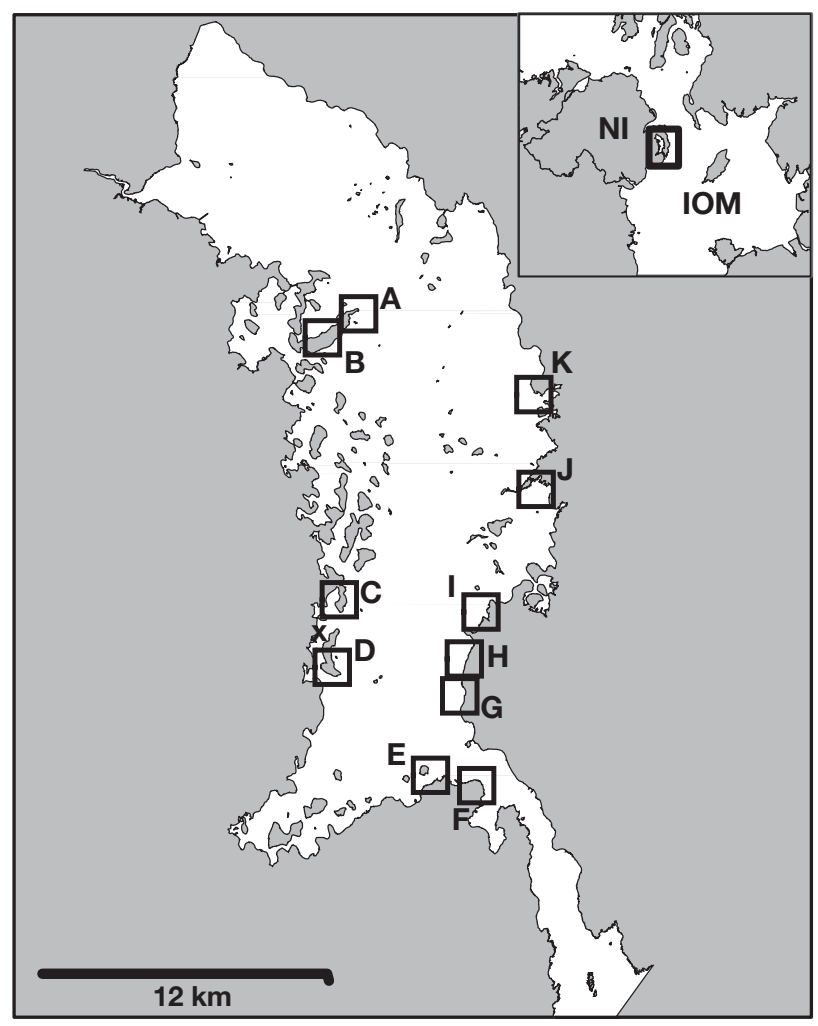

Fig. 1. Strangford Lough and photographed locations $(\mathrm{X}=$ Rathcunningham site; other abbreviations as in Table 1). Inset shows locations of Strangford Lough (box), Northern Ireland (NI) and Isle of Man (IOM) 
Table 1. Algal and mean barnacle cover estimates for each available shore photograph for Strangford Lough. Estimated area of fucoid cover (Fuc. cover) in first photograph of each series was standardised to $100 \%$ cover to allow comparisons of sites where fraction of intertidal varied (as a proportion of the georeferenced 100 ha areas used to overlay photographs in the GIS)

\begin{tabular}{|c|c|c|c|c|}
\hline \multirow{3}{*}{$\begin{array}{l}\text { Site } \\
\text { A: Mahee Island N }\end{array}$} & \multirow{3}{*}{$\begin{array}{l}\text { Year } \\
1962\end{array}$} & \multirow{3}{*}{$\begin{array}{c}\begin{array}{c}\text { Fuc. cover } \\
(\%)\end{array} \\
100\end{array}$} & \multicolumn{2}{|c|}{ Barnacle patches } \\
\hline & & & $\mathrm{n}$ & Size $\left(\mathrm{m}^{2}\right)$ \\
\hline & & & 0 & 0 \\
\hline & 1969 & 100 & 0 & 0 \\
\hline & 1988 & 98.7 & 14 & 73.5 \\
\hline & 1994 & 97.6 & 9 & 211.6 \\
\hline & 1997 & 98.3 & 10 & 135.5 \\
\hline & 2001 & 94.7 & 14 & 293.0 \\
\hline & 2002 & 95.3 & 23 & 158.7 \\
\hline \multirow[t]{3}{*}{ B: Mahee Island S } & 1994 & 100 & 16 & 114.8 \\
\hline & 2001 & 95.9 & 24 & 130.2 \\
\hline & 2002 & 93.7 & 31 & 122.6 \\
\hline \multirow[t]{2}{*}{ C: Ringdufferin } & 1994 & 100 & 9 & 94.3 \\
\hline & 2001 & 99.0 & 18 & 128.2 \\
\hline \multirow[t]{3}{*}{ D: Taggart Island } & 1969 & 100 & 0 & 0 \\
\hline & 1994 & 98.9 & 26 & 56.4 \\
\hline & 2001 & 95.7 & 37 & 149.4 \\
\hline \multirow[t]{2}{*}{ E: Chapel Island } & 1994 & 100 & 4 & 91.9 \\
\hline & 2001 & 99.9 & 5 & 113.9 \\
\hline \multirow[t]{2}{*}{ F: Audley's Castle } & 1994 & 100 & 44 & 72.2 \\
\hline & 2001 & 97.0 & 28 & 148.4 \\
\hline \multirow[t]{2}{*}{ G: Marlfield Bay } & 1994 & 100 & 27 & 40.2 \\
\hline & 2001 & 90.2 & 48 & 86.0 \\
\hline \multirow[t]{2}{*}{ H: Priest Town } & 1994 & 100 & 40 & 95.7 \\
\hline & 2001 & 94.0 & 56 & 116.8 \\
\hline \multirow[t]{2}{*}{ I: Lady's Port } & 1994 & 100 & 13 & 55.5 \\
\hline & 2001 & 99.2 & 11 & 172.4 \\
\hline \multirow[t]{2}{*}{ J: Black Neb } & 1994 & 100 & 27 & 81.1 \\
\hline & 2001 & 99.5 & 28 & 95.0 \\
\hline \multirow[t]{3}{*}{ K: Kircubbin } & 1962 & 100 & 6 & 2.3 \\
\hline & 1994 & 99.3 & 23 & 32.7 \\
\hline & 2001 & 97.4 & 27 & 99.9 \\
\hline
\end{tabular}

quantify in photographs. A fixed 100 ha area was marked out in photographs for each location using a geographical information system (GIS, ArcInfo). This provided a means for standardising comparison of photographs among different dates. Between 5 and 10 control points per location were identified for georeferencing areas in photographs from different dates (Caloz \& Collet 1997) and recorded in the field during 2001 and 2002 using geographical positioning systems (GPS).

Areas of fucoid canopy in photographs contrast sharply with the barnacle cover that dominates in the absence of macroalgae. Although it was not possible to distinguish the Ascophyllum nodosum canopy from other fucoids in photographs, the majority of mid-shore areas in Strangford Lough are dominated by A. nodosum (Brown 1990). The presence of pale white or grey barnacle patches against the darker algal-dominated mid-shore therefore facilitates automated identification of gaps in canopy cover (Ekebom \& Erkkila 2003). This approach was ground-truthed using GPS to trace the outlines of 7 barnacle patches during 2001. In the field an average area of $404.04 \mathrm{~m}^{2}(\mathrm{SE}=145.8)$ was recorded. The same patches were identified in aerial photographs from 2001. An average patch area of $351.06 \mathrm{~m}^{2}(\mathrm{SE}=108.7)$ was recorded $($ error $=13 \%)$. For each photograph, individual barnacle patches were extrapolated into polygon shapefiles to measure patch surface area (total area of barnacle patches in each photographed location) and frequency (number of barnacle patches at each photographed location). The initial cover of algal canopy was measured for the first photograph at each site to provide a baseline to estimate canopy loss. The annual rates of change for barnacle and fucoid cover were estimated from successive pairs of photographs at each site, with data plotted at the mid point of the 2 years used to estimate the rate of change.

Limpet abundances. Several different sets of survey data were collated to estimate the extent of change in limpet abundance over time. Information on limpet density for each aerial photograph location was collected from 20 haphazardly thrown quadrats $\left(0.25 \mathrm{~m}^{2}\right)$ in the intertidal during summer 2002. At Rathcunningham Quay, Strangford Lough (Fig. 1, Site X), the abundance of limpets (Patella vulgata) boulder ${ }^{-1}(\mathrm{n}=232)$ had been surveyed in 1979 (Boaden \& Dring 1980) and the same methodology (Boaden \& Dring 1980) was replicated in $2000(\mathrm{n}=10)$ and $2004(\mathrm{n}=58)$ to remain consistent with earlier counts in 1979. Limpets were counted on boulders with a horizontal circumference of approximately $1 \mathrm{~m}$. In each case, all boulders of the target size were examined, as encountered, along a transect in the mid shore at the Rathcunningham site.

At Taggart Island, Strangford Lough (Fig. 1: Site D) limpet data were available from both the 1986 Northern Ireland Littoral Survey (Wilkinson et al. 1988) and the 2003 Strangford Lough Ecological Change Survey (Roberts et al. 2004). Both surveys used the same methodology. Densities were estimated in $0.25 \mathrm{~m}^{2}$ quadrats $(1986, \mathrm{n}=16 ; 2003, \mathrm{n}=35)$, but converted into an 8-point categorical scale to describe the mean abundance of species within the vertical height limits in which they were found. As the raw data were not available, categorical estimates were backtransformed to estimates of population density by taking the log mid point of each category (thus, a category indicating abundances between 10 and 99 limpets has a mid point of 55 or log mid point of 3.45 , see Burrows et al. 2002). The loss of information during this process is more likely to have obscured differences between surveys than to have created artefactual changes in abundance. 
Physical factors. A cartographic method was used to estimate temporal changes in wave exposure concurrent with the aerial photograph time series. The exposure index was calculated on an annual basis for 400 locations spaced at $0.5 \mathrm{~km}$ intervals along the shoreline of Strangford Lough. As the lough has a narrow connection to the Irish Sea, waves are determined by local winds without any influence from open water swells. The model was based upon 2 factors, fetch distance and consensus wind speed. Using a GIS routine, fetch distances for each of the locations were calculated as the distance of open water along 36 compass bearings at $10^{\circ}$ intervals.

Daily wind records consisting of wind speed and wind direction spanning 1972 to 2003 were obtained from 3 local wind stations situated around the lough $(<2 \mathrm{~km}$ from the shoreline). Data from each wind station were transformed to a mean speed of zero with unit standard deviation to allow records from sites with different mean speeds to be averaged. The consensus wind speeds took into account variable wind speed and direction recorded at different sites as a result of modification by the surrounding topography (Klaic et al. 2002). Therefore, they were considered to be a more reliable basis for extrapolation of wave exposure than records from any single site.

Relative wave exposure was estimated by multiplying the square of average consensus wind speed by the fetch distance along each $10^{\circ}$ bearing (modified after Thomas 1986). To avoid confounding changes in location with time, estimates of the mean exposure and change in exposure were estimated for 1994 to 2001 for each location. These dates provided the highest number of paired photographs $(n=11)$ for comparison over the same time period. The short-term change in exposure at each location was calculated as the rank correlation between annual relative exposure and year. Hence a positive trend in exposure indicates that wind speeds have been increasing between 1994 and 2001 and/or winds along relatively longer fetches are becoming more common for a particular location. In addition to mean relative exposure the variance of the time series was used as a measure of the potential for relatively extreme years to affect algal cover. The 8 yr summaries (mean, variance and trend) were used as predictor variables for the change in patch frequency or area between 1994 and 2001 at the 11 photographed locations. Longer timescale trends in wind speed were analysed using regression to determine whether mean wind speed had decreased or increased over the 1972 to 2003 time period. In case mean wind speed was not a good indicator of the potential for algal loss in storms, the overall trend in records of strong winds to gales (annual proportion of records $>12 \mathrm{~m} \mathrm{~s}^{-1}$ ) was also examined between 1972 and 2003.
Manipulative experiments. To determine the effect of limpets on the frond length of adult Ascophyllum nodosum a hierarchical experimental design was employed. Experiments were carried out in 2 regions, Strangford Lough and the Isle of Man. The Isle of Man lies $70 \mathrm{~km}$ to the SE of Strangford Lough. It was selected as a second region because previous studies have shown it to have a lower density of limpets, yet it is both climatically and biologically similar to Strangford Lough. At the sites used for experiments, the average density of limpets was $29 \mathrm{~m}^{-2}$ at sites in the Isle of Man compared to $115 \mathrm{~m}^{-2}$ in Strangford Lough $\left(0.25 \mathrm{~m}^{2}\right.$ quadrats, $\left.\mathrm{n}=20 \mathrm{site}^{-1}\right)$. Two sites were randomly chosen from those available in each region that exhibited $>50 \%$ cover of $A$. nodosum interspersed with Patella vulgata. At each site, there were 7 replicates of each of 3 treatments. The 3 experimental treatments were (1) square enclosures of $30 \times 30 \mathrm{~cm}$ surrounded by $1 \mathrm{~cm}$ mesh rabbit-wire fences to prevent limpet access (exclusions), (2) partial fences with a gap of $5 \mathrm{~cm}$ in the middle of each side as a procedural control and (3) an open treatment, marked only with screws (controls). Each treatment was centred on an individual adult $A$. nodosum plant, randomly allocated to 1 of the experimental treatments. There was a minimum spacing of $1 \mathrm{~m}$ between experimental replicates. All enclosures and controls were initially cleared of grazers (in May 2002) and frond length of the $A$. nodosum plant standardised to $25 \mathrm{~cm}$. Frond length for each $A$. nodosum individual was recorded at approximately 2 mo intervals for 14 mo. Prior to analysis using a mixed-model ANOVA, data were examined for heteroscedasticity ('cage type' and 'region' as fixed factors, 'site' as random factor, nested within 'region').

Breaking force for Ascophyllum nodosum. The breaking force for $A$. nodosum fronds $(n=94)$ was estimated from haphazardly selected individuals close to the experimental and survey sites. Around the base of each individual, local limpet densities were recorded within an $0.25 \mathrm{~m}^{2}$ quadrat centred on the plant. Breaking force was estimated for 1 randomly selected frond by attaching a grommet below the basal internode (McEachreon \& Thomas 1987). A spring scale (0 to $2500 \mathrm{~g}$ ) with a maximum force recorder was hooked to the grommet and steadily pulled vertically; if the frond did not break, the procedure was repeated on the same frond using a 0 to $10000 \mathrm{~g}$ spring scale. If the breaking force of the second pull did not exceed that of the first pull, weakening of the frond was assumed and the frond omitted from analysis. Broken fronds were retained to record the number of limpet grazing marks (defined as rasped areas formed by the characteristic sweeping movements of limpets per centimetre of frond). 


\section{RESULTS}

\section{Temporal change in barnacle patches and limpet abundances}

There has been a change in algal cover since 1962, when the photographed shores were almost totally covered in algae, to a canopy interspersed with patches of barnacles (Fig. 2). From the predominantly mid-shore development of patches and from examination of locations, it is clear that most of the lost canopy consisted of Ascophyllum nodosum. The rate of patch formation was estimated for successive pairs of photographs at each location. Since 1962, the average annual barnacle patch formation rate at each location has been $1.43 \mathrm{yr}^{-1}$ (SE 0.595, significantly greater than zero in a Student's $t$-test, $\mathrm{p}<0.05)$. Only 3 changes in patch frequency were negative (i.e. a decrease in patches between photos, Fig. 3). For these 3 cases, the corresponding change in barnacle patch area was positive, implying coalescence and expansion of existing patches. The correlation between year and change in patch frequency was positive, implying that the rate of patch formation has increased over time (Spearman's $\left.r_{s}=0.714, p<0.05\right)$. This pattern does not seem to have resulted from changes in the locations used at different times. Individual locations all showed a net increase in patch formation over time (Locations A, B, D and K all increased in rate overall).

As with the patch formation rate, the estimated rate of loss of canopy cover appears to be increasing (Fig. 4). The correlation between rate of change in percentage cover and year was negative, indicating that the loss rate of fucoid cover has increased over time $\left(\mathrm{r}_{\mathrm{s}}=0.479, \mathrm{p}<0.05\right)$. There was an average estimated reduction of $3 \%$ of canopy between 1994 and 2001 (the years for which most data exist). This loss represents a 1.7 ha decrease in algal cover within the lough.

The available data on limpet density imply large increases in limpet density at the surveyed sites. Limpet numbers were greater in recent surveys at both Rathcunningham and Taggart Island (1-way ANOVAs, Rathcunningham: $F_{2,299}=230.59, \mathrm{p}<0.05$; Taggart Island: $F_{1,50}=51.27, \mathrm{p}<0.05$, Fig. 5).

\section{Barnacle patch and limpet densities in relation to physical factors}

There were no clear changes in wind speeds in the consensus data for Strangford Lough over the 1972 to 2003 period. Linear regressions of mean annual wind speed and frequency of strong winds to gales (speeds $>12 \mathrm{~m} \mathrm{~s}^{-1}$ ) were not significant (mean wind speed [negative slope]: $\mathrm{r}^{2}=0.140, \mathrm{p}=0.551$; frequency of
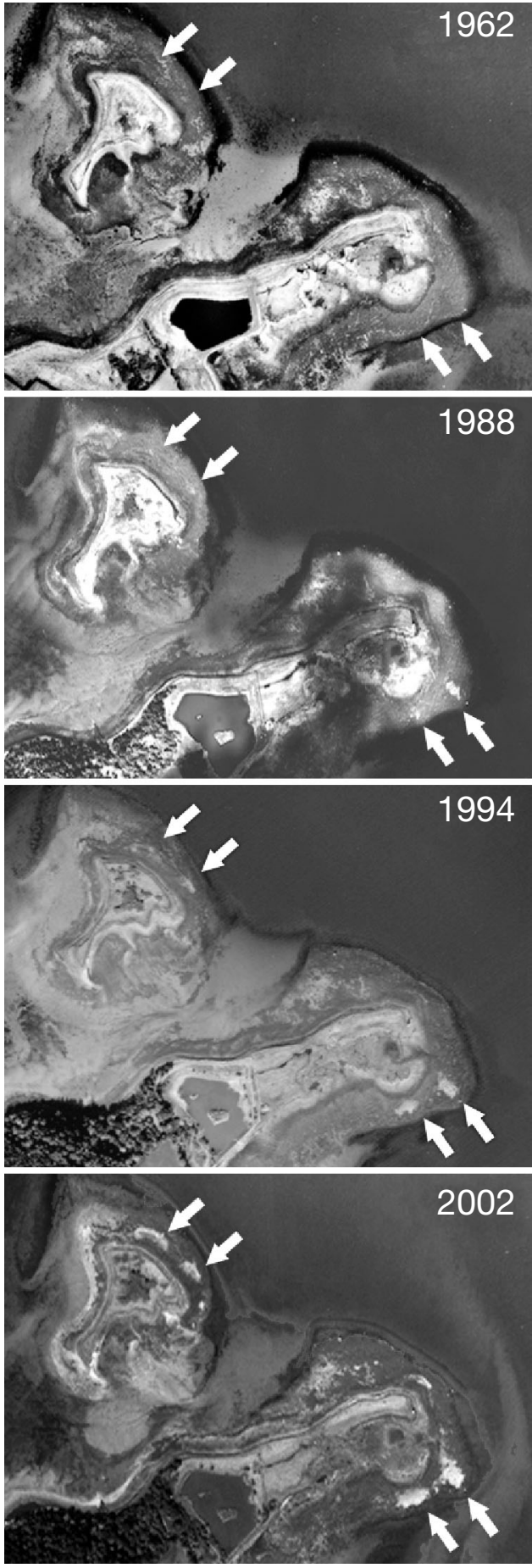

Fig. 2. Development of barnacle patches over time (arrowed) in the intertidal zone of Mahee Island, Strangford Lough. Spacing within pairs of arrows is approximately $50 \mathrm{~m}$

strong winds to gales [negative slope]: $\mathrm{r}^{2}=0.086, \mathrm{p}=$ $0.109)$.

Interactions between wind direction and fetch create variation in wave exposure among locations. This 


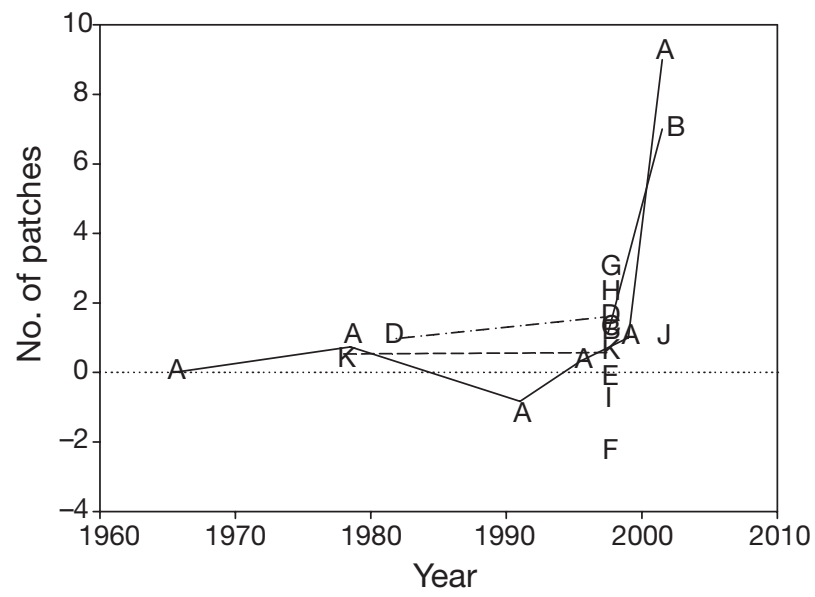

Fig. 3. Rates of change in barnacle patch numbers at each photographed location. Changes calculated as annual net change between successive dates with point plotted at the mid point of the 2 years used to estimate rate of change

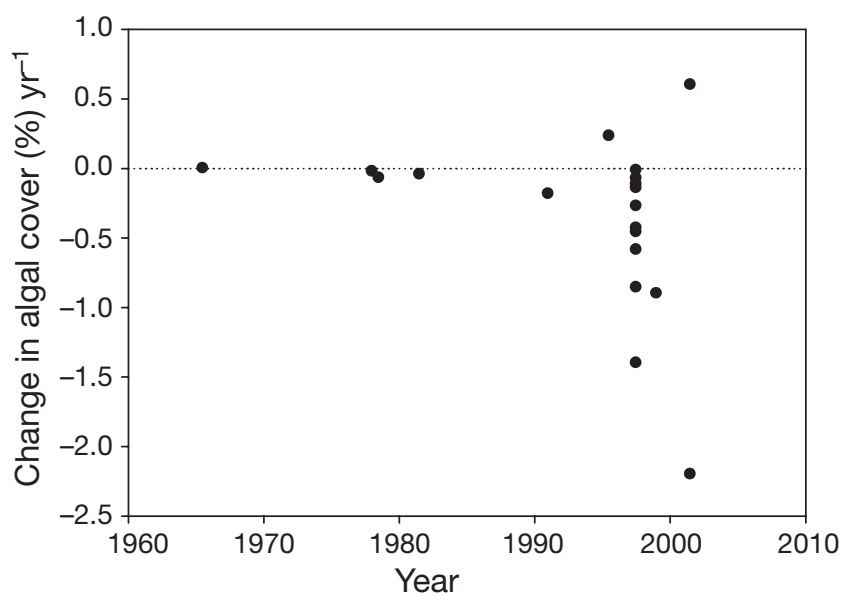

Fig. 4. Ascophyllum nodosum. Percentage change in algal cover between pairs of dated photographs, plotted at midterm point between dates of photographs

variation did not, however, influence the creation of barnacle patches during the 1994 to 2001 period. There was no relationship between the mean relative exposure index, the variance or the temporal trend in the exposure index and changes in patch frequency or the total area of barnacles (Table 2). Relative exposures decreased on average over the photographed locations between 1994 and 2001 (average correlation between annual exposure and year, $r_{s}=-0.62$, SE 0.080, significantly different from zero, Student's $t=$ $7.72, \mathrm{p}<0.05)$. Mean limpet densities at the photographed locations were also unrelated to exposure or patch variables.

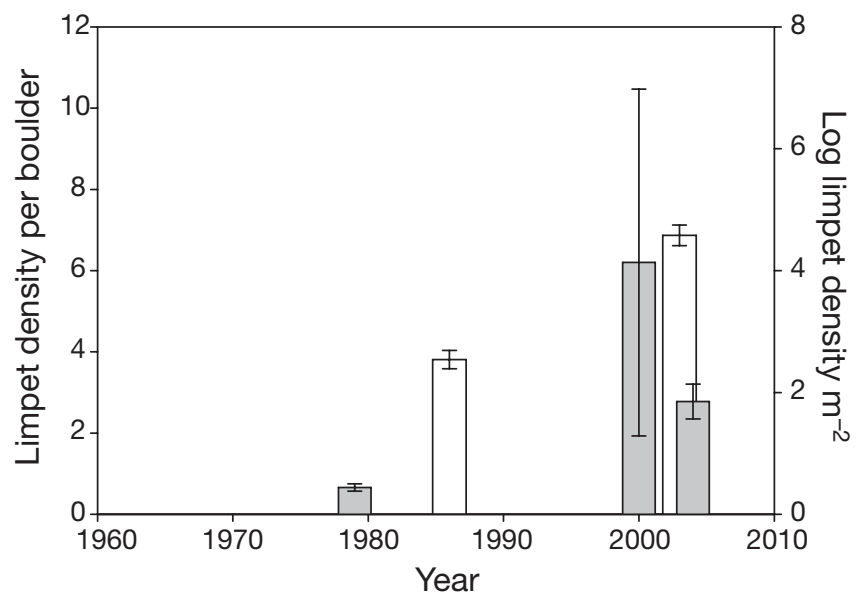

Fig. 5. Patella vulgata. Estimated mean $( \pm$ SE) limpet density in different years at Rathcunningham (shaded bars, left ordinate) and Taggart Island (white bars, right ordinate)

Table 2. Correlations between potential drivers of changes in canopy cover and observed change in canopy cover at each location photographed in both 1994 and $2001(\mathrm{n}=10)$. Patch frequency: number of patches in each photograph; patch area: estimated area of barnacle patches in each photograph. No correlations were significant; lowest probability associated with a coefficient was 0.16

\begin{tabular}{|lrrrr|}
\hline Parameter & \multicolumn{3}{c}{ Relative exposure } & 1994-2001 \\
& Mean & Variance & Trend & $\begin{array}{c}\text { count } \\
(2002)\end{array}$ \\
\hline $\begin{array}{l}\text { Change in } \\
\text { patch frequency } \\
\text { patch area }\end{array}$ & 0.237 & 0.499 & -0.482 & 0.315 \\
\hline
\end{tabular}

\section{Effects of limpets on Ascophyllum nodosum}

The frond lengths of Ascophyllum nodosum individuals after 14 mo were similar in the Isle of Man and Strangford when limpets were prevented from grazing (Fig. 6). The regions differed when comparing acrosscage designs that allowed limpets access to A. nodosum (significant cage type $\times$ region interaction: $F_{2,4}=11.9$, $\mathrm{p}<0.05)$. Frond lengths increased regardless of grazing in the Isle of Man, but there was no net increase in frond lengths of grazed A. nodosum after 14 mo in Strangford. There were no differences between sites within a region (cage type $\times$ site (region) interaction: $\left.F_{4,59}=0.39, \mathrm{p}>0.05\right)$. In Strangford Lough, but not in the Isle of Man, limpets were observed to trap A. nodosum fronds under the shell and graze on the trapped fronds (Fig. 7a,b) and were also commonly observed aggregating around $A$. nodosum holdfasts (Fig. $7 \mathrm{c}$ ). 


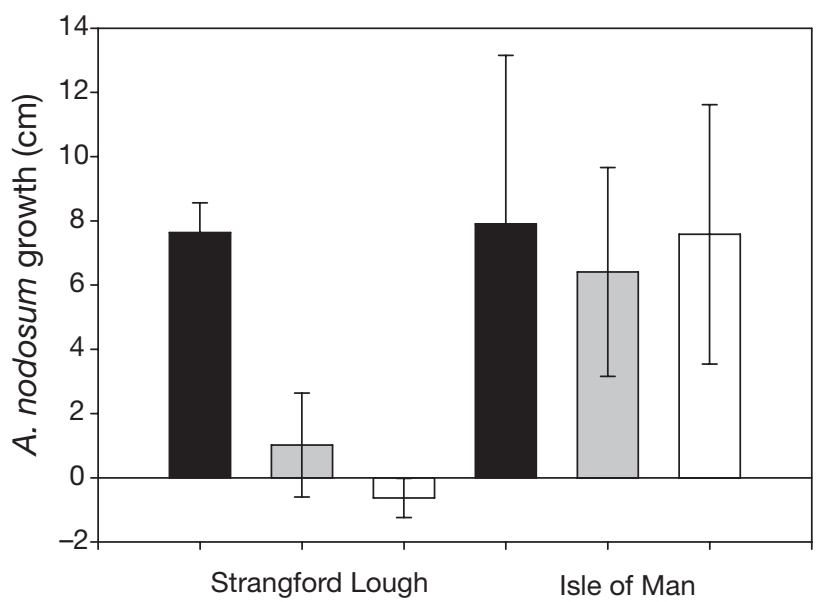

Fig. 6. Ascophyllum nodosum. Mean (+SE) changes in frond length in experimental treatments after 14 mo. Treatments shown as: fences to exclude limpets (black bars), partial fences as a procedural control (grey bars) and unfenced treatments (white bars)

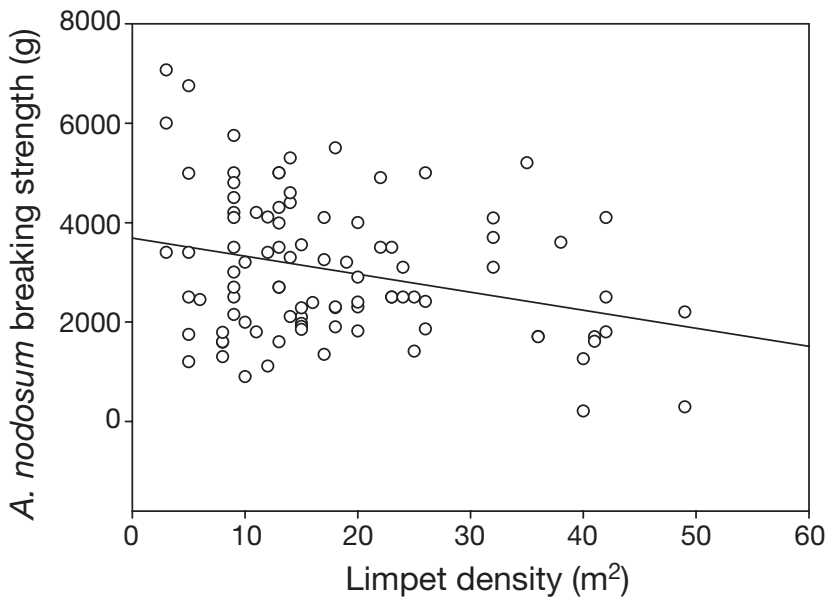

Fig. 8. Ascophyllum nodosum. Relationship between breaking strength and density of Patella vulgata adjacent to holdfast. Fitted line is a linear regression
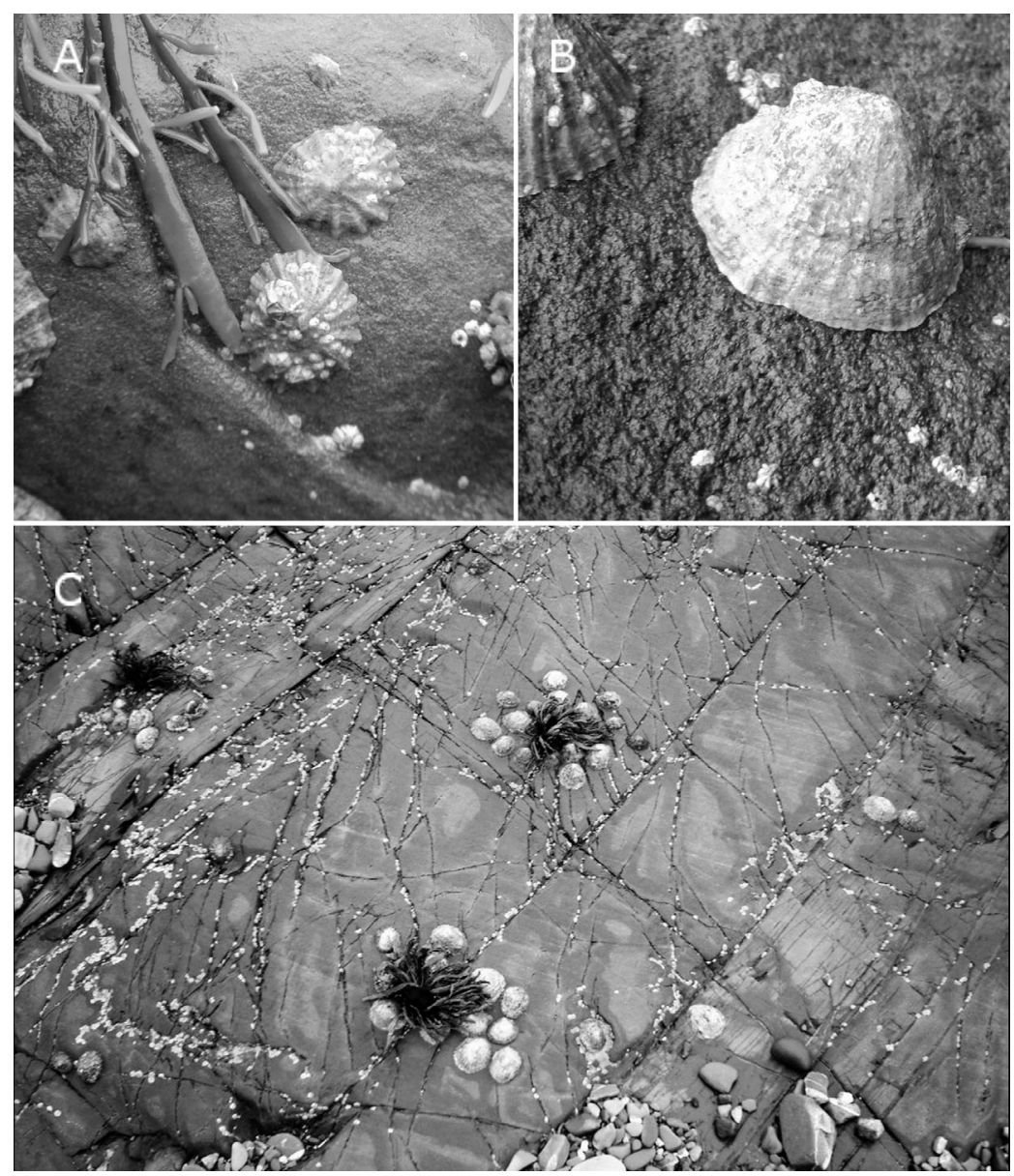

Fig. 7. Patella vulgata. Limpet grazing behaviour in Strangford Lough, showing Ascophyllum nodosum frond trapped under limpet shell at (A) Mahee Island and (B) Marlfield Bay. (C) Limpet clumping behaviour around holdfasts of solitary A. nodosum
Increased densities of limpets were associated with weaker Ascophyllum nodosum fronds (Fig. 8, $\mathrm{r}^{2}=0.085, \mathrm{p}<$ 0.01). A. nodosum with higher densities of limpets in the immediate area had a greater frequency of grazing marks ( $r=0.239, \mathrm{p}<0.05)$, structurally weakening the individual. Grazing therefore seems to increase the sensitivity of $A$. nodosum to frond breakage.

\section{DISCUSSION}

Aerial photographs clearly show the loss of algal canopy from mid-shore hard substrata in Strangford Lough. Over the last few decades, oncecontinuous canopies of Ascophyllum nodosum have become punctuated by barnacle-dominated patches. The rate at which these barnacle patches are created in the algal canopy appears to have increased since 1990 and at the same time the total area of these patches has also been increasing. Such changes in canopy cover, involving the replacement of primary producers with filter-feeders, will influence the ecosystem functioning of the lough, potentially altering the flows of carbon and/or nutrients between the intertidal and other coastal habitats. 
Experimental manipulation of limpet grazing demonstrated that the present densities of limpets in the lough are capable of preventing the growth of established Ascophyllum nodosum. In addition, increased limpet density around holdfasts was associated with decreases in the breaking force of $A$. nodosum fronds. Limpets therefore increase the vulnerability of fronds to wave-induced breakage. In Strangford Lough, the observed increases in limpet densities may therefore cause loss of $A$. nodosum through direct grazing of established plants. Observations after the Torrey Canyon oil spill and in Brittany have previously suggested that extreme increases in limpet density are sufficient to cause the loss of established algal canopies (Southward \& Southward 1978, Hawkins \& Southward 1992, Le Roux 2005).

Demographic and environmental processes may also contribute to the loss of canopy, but there is little evidence for such factors acting in Strangford Lough. A lack of algal recruitment could potentially lead to a decline in canopy as part of an intrinsic long-term cycle, but there is little evidence to support suppression of recruitment by the established canopy. Demographic analyses of Ascophyllum nodosum populations indicate that population growth rate is more sensitive to changes in the survival of existing plants than to variations in recruitment (Åberg 1992a,b). The estimated lifespan of $A$. nodosum holdfasts is 50 to $60 \mathrm{yr}$ in areas with sea ice and will exceed this in ice-free areas (Åberg 1992b). Given such a long lifespan, the loss of canopy during the 1990s must have resulted from an increase in the loss of established A. nodosum. As an alternative to a trophic interaction (grazing), A. nodosum may be responding to other changes in the environment of Strangford Lough. Eutrophication has been associated with decreases in fucoid cover (Vogt \& Schramm 1991), but investigations during the 1990s concluded that Strangford Lough was not eutrophic (Service et al. 1996).

Climate change may affect the geographic distribution of Ascophyllum nodosum. In the Atlantic, fucoids are more common on shores at higher latitudes. Increases in air and sea temperatures are therefore expected to cause the ranges of fucoid algae to move northwards as shores at the southern range limits become too warm (Kendall et al. 2004). Strangford Lough, however, is not at the southern range limit of A. nodosum (Lüning 1990). There is recorded evidence for climate change over the last few decades in Northern Ireland. Air temperatures have increased, leading to fewer frosts, particularly since 1990 (Fig. 9). There are no continuous records of sea surface temperature for Strangford Lough. However, given the lough's estimated flushing time of $1.6 \mathrm{~d}$ (Service et al. 1996), temperature in the lough is expected to be close to that of

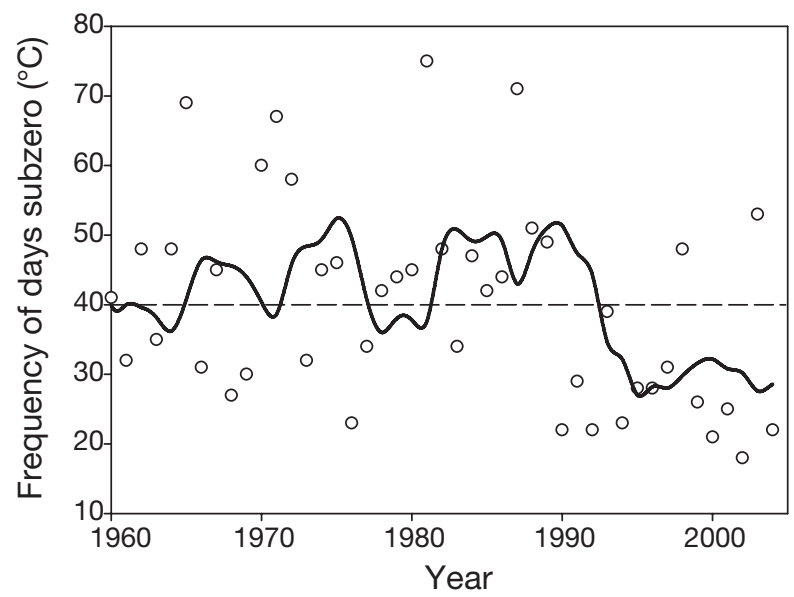

Fig. 9. Frequency of days with surface air temperatures below $0^{\circ} \mathrm{C}$ (Jones \& Lister 2004) at Strangford Lough. Dashed line: mean of time-series; solid line: 5 yr running mean

the Irish Sea. Records from the Port Erin breakwater (Isle of Man) show an increase of approximately $1^{\circ} \mathrm{C}$ in average Irish Sea surface temperatures over the last $100 \mathrm{yr}$, with a current mean of approximately $11^{\circ} \mathrm{C}$ (Evans et al. 2003). Maximum temperatures of $15^{\circ} \mathrm{C}$ were recorded in intertidal areas of Strangford Lough during short-term ( $7 \mathrm{~d}$ ) temperature logging in August (Strong 2003). All these temperatures seem well within the tolerance limits of $A$. nodosum, which has been shown to grow more rapidly with warming until a threshold of between 19 and $25^{\circ} \mathrm{C}$ is reached (Keser et al. 2005). The experimental manipulation in Strangford confirms that adult fronds are capable of growing under current environmental conditions, as long as limpets are excluded.

Ascophyllum nodosum is a sheltered-shore species and canopy loss may therefore be related to increased storm frequency (and therefore waves) as a result of changing wind climate (Thompson et al. 2002). There is no evidence for increases in wind speeds and wave exposure over the last few decades in Strangford. The rates of canopy loss showed no association with variation in mean estimated wave exposure among locations in the lough.

The grazing experiment indicates that the present densities of limpets in Strangford are preventing Ascophyllum nodosum growth by grazing, ultimately causing damage to fronds. A number of factors may have caused the recent increase in mean limpet densities to the level at which canopy cover becomes affected. Changes in climate, particularly from 1990, have led to less severe winter air (Fig. 9) and sea (Evans et al. 2003) temperatures. Limpet recruitment is lower and mortality is higher in cold winters (Crisp 1964, Bowman \& Lewis 1986). The milder winters of the 1990s may therefore have reduced density-independent 
restrictions on limpet populations, leading to the observed increases in population size. Such thermal limits to populations have been suggested for other molluscs (Thieltges et al. 2004). Thermal effects on grazer populations are also apparent from increased population density in response to artificial warming by power station discharges (Schiel et al. 2004). Limpet populations could also have increased due to declines in predator densities; however, evidence from bird counts suggests the opposite. Oystercatchers Haematopus ostralegus L. are considered to be important predators of limpets (Coleman et al. 1999). Bird counts indicate an increase in oystercatcher population size of $83 \%$ over the past $25 \mathrm{yr}$, with the steepest rises occurring in the 1990s (Maclean et al. 2005). This implies that the predation pressure on limpets may have increased during recent decades.

The trend of canopy loss seems likely to continue if limpet populations remain at their current levels within the lough. In the short term, canopy loss may accelerate as observed in the frequency of patch formation and changes in algal canopy since the 1990s. Ascophyllum nodosum canopy indirectly limits limpet populations by supporting an understorey of red algal turf, which is an unsuitable habitat for limpets (Jenkins et al. 1999, 2004). When the turf breaks down following canopy removal, there is often a large increase in limpet density (Jenkins et al. 2004). In Strangford Lough, these new barnacle- and limpet-dominated areas of the mid-shore may be relatively persistent. Other authors have shown that switching between assemblages can be stable and may persist for long periods. For example, Petraitis \& Dudgeon (1999) have suggested that large-scale removal of $A$. nodosum from sheltered shores in New England may lead to a stable alternative assemblage dominated by mussels. Other authors have considered that the factors promoting $A$. nodosum beds are more predictable, such that any disturbed canopy will eventually revert to $A$. nodosum dominance (Bertness et al. 2002, 2004), although the period of recovery may extend over decades (Jenkins et al. 2004). As each of these studies deals with different physical habitats, a generalisation cannot be made about how shores dominated by $A$. nodosum canopies will respond to disturbance.

Ascophyllum nodosum recruits have been observed in locations within Strangford from which limpets have been removed, indicating that $A$. nodosum canopies have the potential to recover (C. A. Maggs unpubl. data). However, it is likely that any future recovery would not occur rapidly. Limpet densities would not decrease immediately with the loss of $A$. nodosum canopy, as the limpets would feed upon the microbial biofilm (Hill \& Hawkins 1991, Thompson et al. 2004) and might seek alternative food supplies such as Fucus spp. (Southward \& Southward 1978). Such patterns were observed after the Torrey Canyon oil spill. Following periods of canopy loss resulting in food shortage, large-scale reductions in limpet density occurred (Southward \& Southward 1978, Hawkins \& Southward 1992). If consumption of $A$. nodosum is subsidising high limpet densities that cannot be sustained by other food sources (see Bustamante et al. 1995), a food shortage and reduction of limpet numbers seems likely if the A. nodosum canopy is totally lost. However, the potential benefits that limpets gain from consuming A. nodosum have not yet been assessed.

The loss of Ascophyllum nodosum in Strangford has parallels with declines in fucoid canopies in the Baltic. Along with eutrophication in the Baltic, increases in grazers (mesograzers: the isopod Idotea baltica Pallas) following mild winters are thought to have caused reduction in algal belt widths and in percentage cover along the coasts of Sweden (Engkvist et al. 2000, Nilsson et al. 2004). The damaging level of canopy grazing observed in Brittany (Le Roux 2005) and the Baltic appears to be a regional phenomenon. It is not always clear why canopy overgrazing should be limited to particular locations. Limpets have been observed grazing on $A$. nodosum fronds in a wide range of locations (e.g. Brittany, France [Le Roux 2005]; Milford Haven, Wales; all Irish coasts; Plymouth, England and west coast of Scotland [C. A. Maggs, M. T. Burrows and S. J. Hawkins, respectively, pers. comm.]). The extent to which this grazing affects canopies may depend on limpet density. Regional variations in climate are likely to influence the density of limpets at broad scales. Local hydrography can further modify recruitment patterns (particularly in restricting grazer populations on the Isle of Man, see Norton et al. 1990 for littorinids). The diversity of observed temporal trends in limpet populations reported by Burrows et al. (2002) presumably reflects these local influences on larval supply and recruitment.

An interaction between limpets and the canopyforming alga Ascophyllum nodosum has been recorded experimentally herein, for the first time. Limpets are increasing in density, perhaps driven by enhanced survivorship through recent favourable winter conditions. Analysis of canopy changes using aerial photographs has shown an accelerated loss of canopy and the continuing emergence of barnacle patches over the last 40 yr. Experimental manipulations have indicated that limpets may be responsible for the loss of established canopy. The limpet $-A$. nodosum interaction demonstrates how separate trophic levels can potentially respond differently to climate change. Assessments of climate change impacts are often made on a single-species basis with respect to the assumed climate envelope required by that species. As limpets 
appear not to respond to the same climatic cues as algae, the predicted shifts in range may be influenced at small scales by mismatches between the responses of fucoids and their most important grazer. If milder winters are acting as a trigger for local increases in limpet abundance, there are likely to be more cases of A. nodosum canopy loss in the temperate NE Atlantic.

Acknowledgements. E. Pothanikat, J. Hodgkinson, C. McIlveen and C. Hetherington surveyed Rathcunningham in 2000. M. Edwards and A. Portig assisted with fieldwork and GIS and data retrieval, respectively. The authors thank Peter Petraitis, Michael Burrows, S. J. Hawkins and 2 anonymous reviewers for valuable comments that improved this manuscript. A.J.D. was supported by a DEL scholarship.

\section{LITERATURE CITED}

Åberg P (1992a) A demographic study of two populations of the seaweed Ascophyllum nodosum. Ecology 73: $1473-1487$

Åberg P (1992b) Size-based demography of the seaweed Ascophyllum nodosum in stochastic environments. Ecology 73:1488-1501

Bertness MD, Trussell GC, Ewanchuk PJ, Silliman BR (2002) Do alternate stable community states exist in the Gulf of Maine rocky intertidal zone? Ecology 83:3434-3448

Bertness MD, Trussell GC, Ewanchuk PJ, Silliman BR, Crain CM (2004) Consumer-controlled community states on Gulf of Maine rocky shores. Ecology 85:1321-1331

Boaden PJS, Dring MJ (1980) A quantitative evaluation of the effects of Ascophyllum harvesting on the littoral ecosystem. Helgol Meeresunters 33:700-710

Bowman RS, Lewis JR (1986) Geographical variation in the breeding cycles and recruitment of Patella spp. Hydrobiologia 142:41-56

Brown R (1990) Strangford Lough, the wildlife of an Irish Sea Lough. Institute of Irish Studies, QUB, Belfast

Burrows MT, Moore JJ, James B (2002) Spatial synchrony of population changes in rocky shore communities in Shetland. Mar Ecol Prog Ser 240:39-48

Bustamante RH, Branch GM, Eekhout S (1995) Maintenance of an exceptional intertidal grazer biomass in South Africa: subsidy by subtidal kelps. Ecology 76:2314-2329

Caloz R, Collet C (1997) Geographic information systems (GIS) and remote sensing in aquatic botany: methodological aspects. Aquat Bot 58:209-228

Coleman RA, Goss-Custard JD, Durell S, Hawkins SJ (1999) Limpet Patella spp. consumption by oystercatchers Haematopus ostralegus: a preference for solitary prey items. Mar Ecol Prog Ser 183:253-261

Cousens R (1984) Estimation of annual production by the intertidal brown algae Ascophyllum nodosum. Bot Mar 27: 217-227

Crisp DJ (1964) The effects of the severe winter of 1962-63 on marine life in Britain. J Anim Ecol 33:165-210

Dudgeon S, Petraitis PS (2001) Scale-dependent recruitment and divergence of intertidal communities. Ecology 82: 991-1006

Dudgeon S, Petraitis PS (2005) First year demography of the foundation species, Ascophyllum nodosum, and its community implications. Oikos 109:405-415

Dye AH (1998) Community-level analyses of long-term changes in rocky littoral fauna from South Africa. Mar Ecol Prog Ser 164:47-57

Ekebom J, Erkkila A (2003) Using aerial photography for identification of marine and coastal habitats under the EU's Habitats Directive. Aquat Conserv: Mar Freshw Ecosyst 13:287-304

Engkvist R, Malm T, Tobiasson S (2000) Density dependent grazing effects of the isopod Idotea baltica Pallas on Fucus vesiculosus L. in the Baltic Sea. Aquat Ecol 34: 253-260

Evans GL, Hardman-Mountford NJ, Hartnoll RG, Kennington K, Mitchelson-Jacob EG, Shammon T, Williams PJLeB (2003) Long-term environmental studies in the Irish Sea: a review. Scientific Rep No. 02 Defra Contract CDEP 84/5/311, Marine Biological Association, Plymouth

Fischer-Piette E (1948) Sur les éléments de prospérité des patelles et sur leur spécificité. J Conchol 88:45-96

Hawkins SJ (1981) The influence of Patella grazing on the fucoid/barnacle mosaic on moderately exposed rocky shores. Kiel Meeresforsch 5:537-543

Hawkins SJ, Hartnoll RG (1983) Grazing of intertidal algae by marine invertebrates. Oceanogr Mar Biol Annu Rev 21: 195-282

Hawkins SJ, Southward AJ (1992) The Torrey Canyon oil spill: recovery of rocky shore communities. In: Thayer GW (ed) Restoring the nation's marine environment, Maryland Sea Grant College, College Park, MD, p 583-631

Hill AS, Hawkins SJ (1991) Seasonal and spatial variation of epilithic microalgal distribution and its ingestion by Patella vulgata on a moderately exposed rocky shore. J Mar Biol Assoc UK 71:403-423

Jenkins SR, Hawkins SJ, Norton TA (1999) Direct and indirect effects of a macroalgal canopy and limpet grazing in structuring a sheltered inter-tidal community. Mar Ecol Prog Ser 188:81-92

Jenkins SR, Norton TA, Hawkins SJ (2004) Long term effects of Ascophyllum nodosum canopy removal on mid shore community structure. J Mar Biol Assoc UK 84:327-330

Jones NS (1946) Browsing of Patella. Nature 158:557-558

Jones NS (1948) Observations and experiments on the biology of Patella vulgata at Port St. Mary, Isle of Man. Proc Trans Liverp Biol Soc 56:60-77

Jones PD, Lister D (2004) The development of monthly temperature series for Scotland and Northern Ireland. Int $\mathrm{J}$ Climatol 24:569-590

Jonsson PR, Granhag L, Moschella PS, Åberg P, Hawkins SJ, Thompson RC (2006) Interactions between wave action and grazing control the distribution of intertidal macroalgae. Ecology 87:1169-1178

Kendall MA, Burrows MT, Southward AJ, Hawkins SJ (2004) Predicting the effects of marine climate change on the invertebrate prey of the birds of rocky shores. Ibis 146 : 40-47

Keser M, Larson BR (1984) Colonization and growth of Ascophyllum nodosum (Phaeophyta) in Maine. J Phycol 20: 83-87

Keser M, Swenarton JT, Foertch JF (2005) Effects of thermal input and climate change on growth of Ascophyllum nodosum (Fucales, Phaeophyceae) in Eastern Long Island Sound (USA). J Sea Res 54:211-220

Klaic ZB, Nitis T, Kos I, Moussiopoulos N (2002) Modification of the local winds due to hypothetical urbanization of the Zagreb surroundings. Meteorol Atmos Phys 79:1-12

Le Roux A (2005) Les patelles et la régression des algues brunes dans le Morbihan. Penn Bed 192:1-22

Lewis JR (1964) The ecology of rocky shores. English Universities Press, London 
Little C, Kitching JA (1996) The biology of rocky shores. Oxford University Press, New York

Lüning K (1990) Seaweeds: their environment, biogeography, and ecophysiology. Wiley-Interscience, New York

Maclean IMD, Austin GE, Mellan HJ, Girling T (2005) WeBS alerts 2003/2004: changes in numbers of wintering waterbirds in the United Kingdom, its constituent countries, special protection areas (SPAs) and sites of special scientific interest (SSSIs). BTO Res Rep. 416 to the WeBS partnership. British Trust for Ornithology (BTO), Thetford

McEachreon JCT, Thomas MLH (1987) Attachment strength of Ascophyllum nodosum (L.) Le Jolis and exposure to wave action. Bot Mar 30:217-222

Nilsson J, Engkvist R, Persson LE (2004) Long-term decline and recent recovery of Fucus populations along the rocky shores of southeast Sweden, Baltic Sea. Aquat Ecol 38:587-598

Norton TA, Hawkins SJ, Manley NL, Williams GA, Watson DC (1990) Scraping a living - a review of littorinid grazing. Hydrobiologia 193:117-138

Petraitis PS, Dudgeon SR (1999) Experimental evidence for the origin of alternative communities on rocky intertidal shores. Oikos 84:239-245

Roberts D, Davies C, Mitchell A, Moore H and 7 others (2004) Strangford Lough ecological change investigation (SLECI). Environment and Heritage Service, Belfast

Schiel DR, Steinbeck JR, Foster MS (2004) Ten years of induced ocean warming causes comprehensive changes in marine benthic communities. Ecology 85:1833-1839

Service M, Durrant AE, Mills JA, Taylor JE, Faughey D (1996) The trophic status of two Northern Irish Sea Loughs. J Coast Conserv 2:159-168

Editorial responsibility: Roger Hughes (Contributing Editor), Bangor, UK
Southward AJ (1964) Limpet grazing and the control of vegetation on rocky shores. In: Crisp DJ (ed) Grazing in terrestrial and marine environments. Blackwell Scientific Publications, Oxford, p 165-273

Southward AJ, Southward EC (1978) Recolonisation of rocky shores in Cornwall after use of toxic dispersants to clear up the Torrey Canyon spill. J Fish Res Board Can 35:682-706

Strong J (2003) The environmental impact of Sargassum muticum on the coastline of Northern Ireland. PhD thesis, Queen's University, Belfast

Thieltges DW, Strasser M, van Beusekom JEE, Reise K (2004) Too cold to prosper - winter mortality prevents population increase of the introduced American slipper limpet Crepidula fornicata in northern Europe. J Exp Mar Biol Ecol 311:375-391

Thomas MLH (1986) A physically derived exposure index for marine shorelines. Ophelia 25:1-13

Thompson RC, Crowe TP, Hawkins SJ (2002) Rocky intertidal communities: past environmental changes, present status and predictions for the next 25 years. Environ Conserv 29: 168-191

Thompson RC, Norton TA, Hawkins SJ (2004) Physical stress and biological control regulate the producer-consumer balance in intertidal biofilms. Ecology 85:1372-1382

Underwood AJ (2000) Experimental ecology of rocky intertidal habitats: What are we learning? J Exp Mar Biol Ecol 250:51-76

Vogt H, Schramm W (1991) Conspicuous decline of Fucus vesiculosus in Kiel Bay (Western Baltic): What are the causes? Mar Ecol Prog Ser 69:189-194

Wilkinson M, Fuller IA, Telfer TC, Moore CG, Kingston PF (1988) Northern Ireland littoral survey. Environment and Heritage Service, Belfast

Submitted: July 13, 2006; Accepted: October 23, 2006 Proofs received from author(s): May 21, 2007 